\title{
THE GEOLOGY, MINERALOGY AND RARE ELEMENT GEOCHEMISTRY OF THE GEM DEPOSITS OF SRI LANKA
}

\author{
C.B. DISSANAYAKE\#, ROHANA CHANDRAJITH and H.J. TOBSCHALL
}

DISSANAYAKE, C.B., CHANDRAJITH, ROHANA and TOBSCHALL, H.J. 2000. The geology, mineralogy and rare element geochemistry of the gem deposits of Sri Lanka. Bulletin of the Geological Society of Finland 72, Parts 12, 5-20.

The gem deposits of Sri Lanka are studied from the point of view of their geology, mineralogy and geochemistry. Nearly all the gem formations are located in the central high-grade metamorphic terrain of the Highland Complex. The gem deposits are classified as sedimentary, metamorphic and magmatic; the sedimentary types being the most abundant. The mineralogy of the gem deposits varies widely with, among others, corundum, chrysoberyl, beryl, spinel, topaz, zircon, tourmaline, garnet and sphene being common.

Rare element concentrations in sediments from the three main gem fields of Sri Lanka, namely Ratnapura, Elahera and Walawe, were studied. It was found that some sediments are considerably enriched in certain elements compared to their average continental crustal abundances. The Walawe Ganga sediments show anomalous enrichments of the high field strength and associated elements, particularly $\mathrm{Zr}$, Hf, W and Ti. This is attributed to the presence of accessory minerals such as zircon, monazite and rutile. Some of these heavy minerals comprise as much as $50 \mathrm{wt} \%$ of sediment. The geochemical enrichment of some trace elements compared to their average crustal abundances indicates that highly differentiated granites and associated pegmatites have provided the source materials for enrichment.

Key words: gems, sediments, geochemistry, trace elements, enrichment, mineralogy, Sri Lanka

C.B. Dissanayake: Department of Geology, University of Peradeniya, Peradeniya, Sri Lanka.

E-mail: cdissa@geol.pdn.ac.lk

Rohana Chandrajith* and H.J. Tobschall: University of Erlangen-Nürnberg, Institute of Geology and Mineralogy, Chair of Applied Geology, Schlossgarten 5, D-91054 Erlangen, Germany

\# Corresponding Author

* Present Address: Department of Natural Resources, Faculty of Applied Sciences, Sabaragamuwa University of Sri Lanka, Buttala, Sri Lanka 


\section{INTRODUCTION}

It has been estimated that nearly $25 \%$ of the total land area of Sri Lanka is potentially gem-bearing, making Sri Lanka one of the countries richest in gems (Dissanayake 1991, Dissanayake \& Rupasinghe 1993). During the past few decades, many new gemstones and hitherto unknown, yet interesting, gem quality minerals have been discovered. The gem fields of Sri Lanka contain about 75 varieties and sub-varieties of gemstones, some in abundance and some as rarities, which occur both among gem gravels and as components of numerous rock types (Gunaratne \& Dissanayake 1995). Many of these gem minerals are unique and have recently been the subject of much research.

The geology, mineralogy and geochemistry of the gem-bearing terrains of Sri Lanka have not been fully investigated. These gem deposits and occurrences are set in a high-grade metamorphic Precambrian terrain, and display unique geological and mineralogical features that are worthy of thorough scientific investigation. Up to now very little work has been carried out on these trace element-enriched stream sediments that drain the gem-bearing terrains in Sri Lanka. Of particular interest are the occurrences of minerals that are abundant in rare elements and the probable mechanisms of their enrichment in source rocks and sediments.

Recently, the gem-bearing sediments of some of the rivers draining the gem fields of Sri Lanka have been shown to be highly enriched in certain trace elements, including rare-earth elements (REE), Zr, Hf, Ta and Nb (Rupasinghe \& Dissanayake 1984, Dissanayake \& Rupasinghe 1986, Dissanayake et al. 1994). Investigations on the stream sediment geochemistry of the Walawe Ganga Basin of Sri Lanka (Chandrajith 1999) have shown very high enrichment factors for some of the trace elements mentioned above, thus indicating the existence of mineralized terrains within the gem fields. Therefore, the origin of the gemstones and the enrichment of these elements appear to be related genetically.

This paper reviews the present understanding of the geology, mineralogy and geochemistry of the gem deposits of Sri Lanka. Further, it is anticipated that research on the stream sediment geochemistry of the gem-bearing terrains of Sri Lanka will contribute to the further understanding of their mineralization mechanisms and to the development of mineral exploration strategies.

\section{GEM DEPOSITS OF SRI LANKA AND THEIR GEOLOGIC SETTING}

\section{General geology of Sri Lanka}

Geologically, Sri Lanka is dominated by Precambrian high-grade metamorphic rocks and can be divided into three major lithotectonic units, namely the Highland Complex, the Vijayan Complex and the Wanni Complex (Cooray 1994). Among these, the Highland Complex is the largest unit and forms the backbone of the Precambrian bedrock of Sri Lanka. Included in this unit are the supracrustal rocks and a variety of igneous intrusions, predominantly of granitoid composition, that are represented by banded gneisses (Kröner et al. 1991). The rocks comprising the Highland Complex were mostly metamorphosed under granulite facies conditions. There has been widespread formation of incipient (arrested) charnockite within this unit (Hansen et. al. 1987) Elsewhere, other granulite types, quartz-feldspar-garnet-sillimanitegraphite schists, quartzites, marbles and calc-silicate gneisses are prominent.

The Vijayan Complex lying to the east of the Highland Complex (Fig. 1) consists of biotitehornblende gneisses and scattered bands of metasediments and charnockitic gneisses. It also comprises small plutons of granite and acid charnockites (Jayawardena \& Carswell 1976) and a NWtrending suite of dolerite dikes. Milisenda et al. (1991) have described the gneissose granitoids of the Vijayan Complex as tonalitic to leucogranitic in composition. The Vijayan Complex, which comprises rocks mostly in the amphibolite facies, has not been subjected to granulite facies metamorphism and this fact has been interpreted by Kröner et al. (1991) to infer that the charnockitic bodies within the Vijayan domain are klippes and/ 


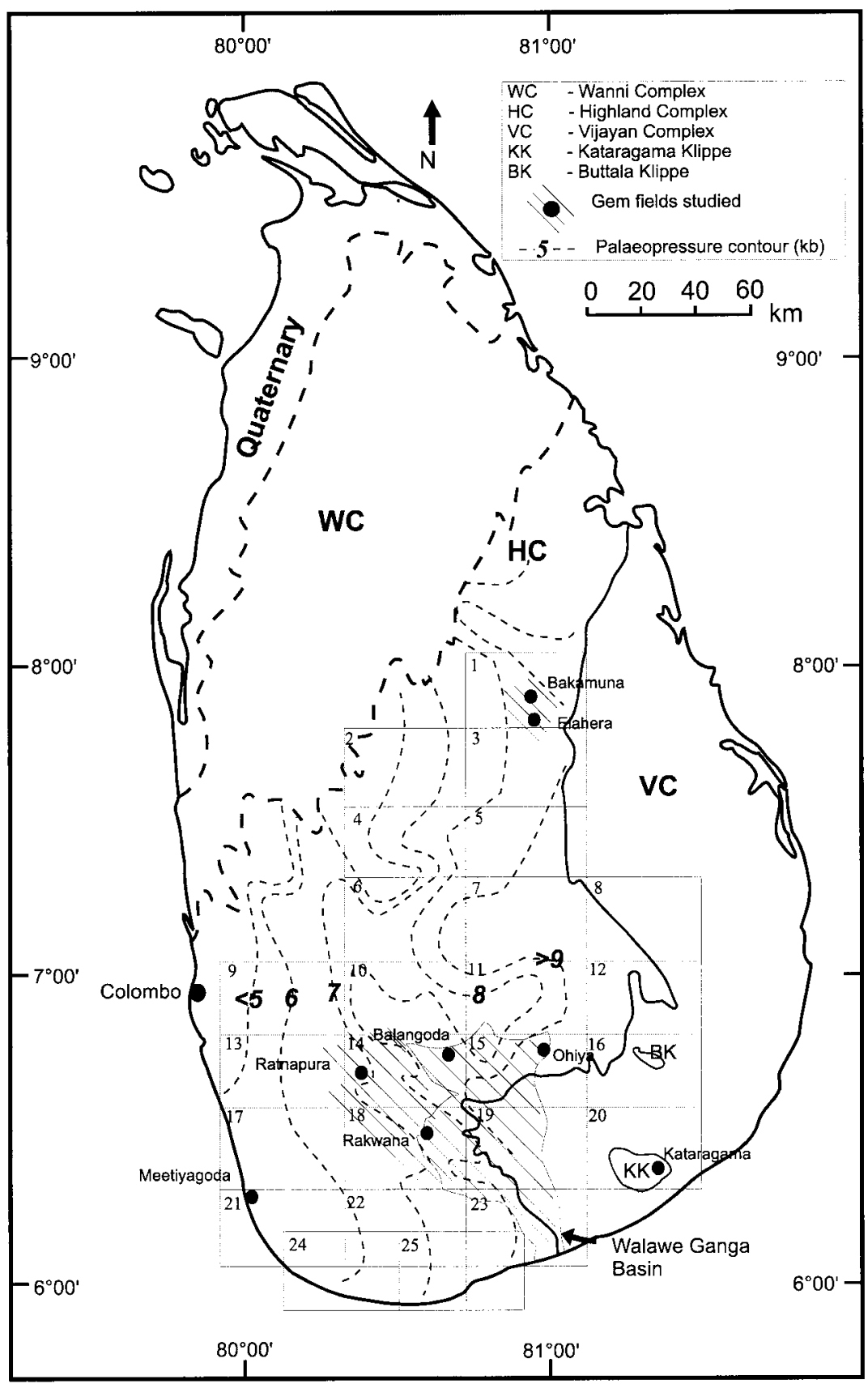

Fig. 1. Map of Sri Lanka showing the main lithotectonic units and the gem fields studied. The boundary between the Highland Complex and Wanni Complex is uncertain and is denoted by a broken line. The numbered sequences represent the topographic sheets. 1: Polonnaruwa, 2: Nalanda, 3: Elahera, 4: Kurunegala, 5: Rangala, 6: Kandy, 7: Hanguranketa, 8: Nilgala, 9: Avissawella, 10: Hatton, 11: Nuwara Elliya, 12: Passara, 13: Panadura-Horana, 14: Ratnapura, 15: Haputale, 16: Buttala, 17: Alutgama, 18: Rakwana, 19: Timbolketiya, 20: Kataragama, 21: Ambalangoda, 22: Morawaka, 23: Ambalantota, 24: Galle, 25: Matara. The palaeopressure contours of the Highland Complex of Sri Lanka in relation to the locations of the gem fields are also shown. Data sources: Prame (1991), Schenk et al. (1991). 
or unfolded or intersliced fragments of the Highland Complex. These are similar to the Kataragama Klippe which is derived from the latter complex (Cooray 1984, Vitanage 1985).

The Wanni Complex consists of granitoid gneisses, charnockitic gneisses and granites. Milisenda et al. (1991) showed that these rocks are mainly amphibolite to granulite facies metasedimentary rocks of predominantly pelitic to semipelitic composition. Studies of detrital zircons from metapelites have shown that the Wanni Complex is younger than the Highland Complex, even though the boundary between these units is poorly defined.

\section{Geological conditions of gem mineral formation}

The centrally located granulite grade Highland Complex is about $30000 \mathrm{~km}^{2}$ in area and presumably contains the host rocks for the gems. The study of Schenk et al. (1991) showed that metamorphic pressures are zoned within the Highland Complex. Cordierite- and garnet-cordierite-bearing metapelitic assemblages, indicative of relatively low pressures, are restricted to the western and northwestern part of the complex, whereas garnetsillimanite \pm biotite-bearing assemblages are predominant in the southeast, in the east and in the Kataragama Klippe. Notably, the garnet-sillimanite \pm biotite-bearing assemblages are absent in the western part. Schenk et al. (1991) concluded that the peak pressures in the southeastern Highland Complex were between 8 and $10 \mathrm{kbar}$ and decreased to 7 and 6 kbar in the west (Fig. 1). They showed that the Highland Complex does not represent a single level in a former lower continental crust, but a more or less continuous section of the lower crust with a vertical thickness of about $15 \mathrm{~km}$. In the southeast, the exposed crust is estimated to have been originally at a depth of about 30-35 km, whereas the exposed rocks in the west were originally at a depth of about $15-20 \mathrm{~km}$.

The gem fields of Sri Lanka are mostly located within the high-pressure region in the southeast (see Fig. 1) and in some northern regions (e.g. Elahera). They are much less prominent in regions of lower pressure. Gem minerals are absent in the Vijayan Complex which does not have pyroxene \pm garnet-bearing assemblages. The temperatures of formation of the gem minerals within the Highland Complex are estimated to range from about $700{ }^{\circ} \mathrm{C}$ to $900{ }^{\circ} \mathrm{C}$ (Prame 1991).

Nearly all the gem deposits of Sri Lanka are derived from the granulite facies rocks of the Highland Complex (Fig. 1), clearly indicating that there were petrological conditions suitable for the formation of gemstones. Gemstones found within the Vijayan domain have been transported by rivers from the Highland Complex.

The source rocks of the gem minerals are skarns, marbles, pegmatites, garnetiferous gneisses and the contact rocks of charnockites (Dissanayake \& Rupasinghe 1995). Recent research (Silva \& Siriwardena 1988, Mendis et al. 1993) has shown that these calcium-rich rocks were particularly suitable as source rocks for the gemstones. Rupasinghe and Dissanayake (1985) discussed the importance of charnockites as a heat source for the contact metamorphism of limestone and aluminous metasediments. Earlier, Munasinghe and Dissanayake (1981) constructed a sequence of events that they thought were significant in bringing about gem mineralization:

1. Deposition of argillaceous sediments in the Highland Basin (the present Highland Complex) during the Archaean. These were presumably derived from weathering and transportation of material from a continental crust.

2. Deformation and metamorphism of sediments during a collisional orogeny. The granulite facies conditions attained favoured the formation of gem minerals such as garnet, sillimanite, andalusite and cordierite.

3. Basement remobilization associated with collision and the emplacement of basic and ultrabasic igneous rocks. Subsequent desilication, caused by the contact metamorphic effects of charnockites and other basic intrusions, formed corundum and spinels.

4. Intrusion of pegmatites enriched in $\mathrm{Be}$ and $\mathrm{F}$ into the basic and ultrabasic rocks within the metasediments of the Highland Complex. Gem 
minerals such as beryl, chrysoberyl, topaz and tourmaline are assumed to have been formed in this manner.

The presence of Al-rich metasediments, regimes of high $\mathrm{P}$ and high $\mathrm{T}$, contact metamorphism, and extensive fluid activity were prerequisite for gem formation within the Highland Complex of Sri Lanka.

\section{CLASSIFICATION OF THE GEM DEPOSITS OF SRI LANKA}

Fig. 2 illustrates the classification scheme for the gem deposits of Sri Lanka proposed by Dissanayake and Rupasinghe (1995). The scheme follows the general classification of the three main rock types and classification is based on deposit gene- sis. The advantage of the genetic classification of gem deposits lies in its predictive value. For example, contact metamorphic zones associated with calcium-rich rocks are likely loci for certain gem deposits in Sri Lanka and identification of such features assists in the location of target areas for detailed exploration.

\section{Sedimentary gem deposits}

Sedimentary gem deposits are by far the most important of all gem deposits in Sri Lanka and were classified by Dahanayake et al. (1980) into residual, eluvial and alluvial types. The sedimentary placer gem deposits occur in thin layers or lenses of gravel and sand, termed locally as Illam, in river beds and alluvial plains and on hillslopes and hillsides. Among the most important factors that govern the depositional nature of these gem

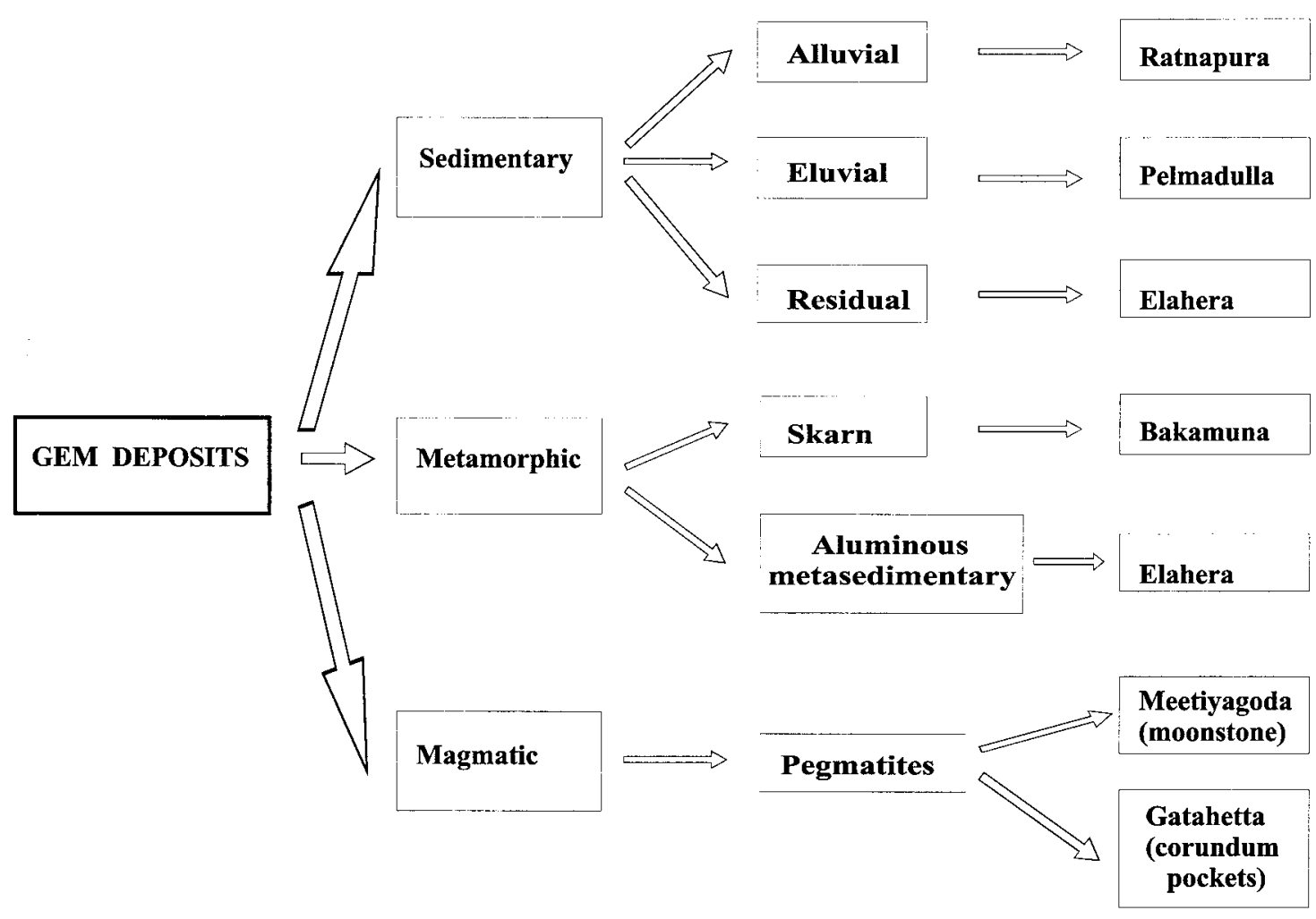

Fig. 2. Classification of the gem deposits of Sri Lanka with examples of locations of different types (modified after Dissanayake \& Rupasinghe 1995). 
deposits are the intensity and distance of transportation from the source and the topographical suitability of the sites for deposition.

The residual gem deposits occur as beds containing gem minerals mostly deposited in-situ and are found at depths ranging from a few centimetres to about 10 metres. These deposits mostly occur on the flood plains of rivers and streams and their sources are assumed to be in the close vicinity. A characteristic feature of the residual gem deposits is the presence of layers of alternating sand, clays and laterites containing angular fragments, as exemplified by the Elahera gem deposit.

The eluvial sedimentary gem deposits are found on hillslopes and flat areas incised by valleys. Often, the eluvial deposits grade into alluvial deposits making identification difficult. The presence of rock fragments and the angular to sub-rounded nature of the gem minerals are characteristic of the eluvial beds.

Alluvial gem deposits are the most widely distributed gem deposit type in Sri Lanka, the Ratnapura gem deposits being a good example. They often reach depths of more than 20 metres and usually contain two or three gem-bearing layers. They occur mostly in old stream terraces and flood plains and are characterized by well-rounded grains. The gem-bearing layers in these alluvial deposits are markedly heterogeneous exhibiting a variety of shapes and sizes that indicate frequent changes in stream courses and velocity.

\section{Metamorphic gem deposits}

Most of the gem deposits in Sri Lanka are clearly of metamorphic genesis reflecting the fact that approximately $90 \%$ of Sri Lanka comprises highgrade metamorphic rocks. Intense tropical weathering has decomposed and disintegrated the gembearing rocks to form sedimentary gem deposits.

\section{Skarn and calcium-rich rock types}

Recent research has shown that calcium-rich bedrock is a source for gem minerals within the metamorphic terrain of Sri Lanka. Maesschalck and Oen (1989) studied the mineral and fluid inclu- sions in gem corundums from Sri Lanka and noted that all the fluid inclusions are pure $\mathrm{CO}_{2}$. Thus $\mathrm{CO}_{2}$ is an important indicator of the genesis of the gem minerals. The microthermometry results for the primary inclusions suggested that these corundums formed under granulite facies metamorphism (> $630^{\circ} \mathrm{C}, 5.5 \mathrm{kbar}$ ), while the presence of secondary fluid inclusions indicated retrograde postmetamorphic cooling and uplift of the source areas. Further, the high density of the fluid inclusions (average density $\mathrm{d}=1.05 \mathrm{~g} / \mathrm{cm}^{3}$ ) was considered as being compatible with the formation of corundum under granulite facies metamorphism. Silva and Siriwardena (1988) described an example of a corundum-bearing skarn deposit, located at Bakamuna near the main Elahera gem field. Cooray (1984), and Wadia and Fernando (1945) describe some other examples of this type, at Elahera and at Ohiya respectively.

\section{Aluminous metasedimentary rock types}

One of the characteristic features of the Highland Complex is the abundance of aluminous metasedimentary rocks. These have the chemical composition required for the formation of corundum and other aluminous gem minerals. It is clear that in the Highland Complex a combination of the P-T conditions and a suitable chemical composition has yielded voluminous sources for gems of this type. Katz (1986) suggested that these gemstones have an origin related to granulite facies metamorphism involving $\mathrm{CO}_{2}$ flooding, the purging of $\mathrm{H}_{2} \mathrm{O}$-rich fluids and partial melting. Cooray and Kumarapeli (1960) studied the occurrence of corundum in biotite-sillimanite gneiss and ascribed its origin to recrystallization and metamorphic differentiation with the formation of aluminium-rich, silica-poor bands in a semipelitic gneiss.

\section{Gems of pegmatitic origin}

Pegmatites are common in the Highland Complex and they are also considered as important sources of gem minerals. One of the best known pegmatitic gem deposits is the moonstone deposit at Meetiyagoda, southern Sri Lanka (Spencer 
1930, Malley 1989). In addition, moonstones have been located in regions around Balangoda and Kundasale near Kandy. Pegmatites in Sri Lanka also contain gem minerals such as beryl, chrysoberyl, zircon and corundum (Rupasinghe et al. 1994).

\section{GEM LOCALITIES IN SRI LANKA}

\section{The Ratnapura gem field}

The Ratnapura gem field is by far the most important gem field in Sri Lanka. The gem deposits of this vast field are of alluvial and eluvial types. As shown in Fig. 3, except for scattered patches of alluvium, the areas covered by the main Ratnapura gem field consist of Precambrian metamorphic rocks of charnockite-metasedimentary type. The main rock types are charnockites, garnet-sil- limanite granulites, amphibolites and perthitebearing garnet-biotite granulitic gneisses. Of these, charnockites and pelitic garnet-sillimanite granulites are the most abundant. The occurrence of intrusive rocks of zircon-bearing granites, vein quartz and pegmatites is of particular significance.

The Ratnapura gem field consists of Pleistocene or sub-recent alluvium with patches or streaks of gravel of heavy minerals laid down in flood plains of streams, either in the beds of abandoned tributaries or in talus fans at the foot of steep hillslopes (Wadia \& Fernando 1945). The heavy minerals including gems were deposited during periods of intense flooding that caused their mechanical removal from their source areas.

\section{The Elahera gem field}

The Elahera gem field, located in northeastern Sri Lanka (Figs. 1 and 4), has produced a significant

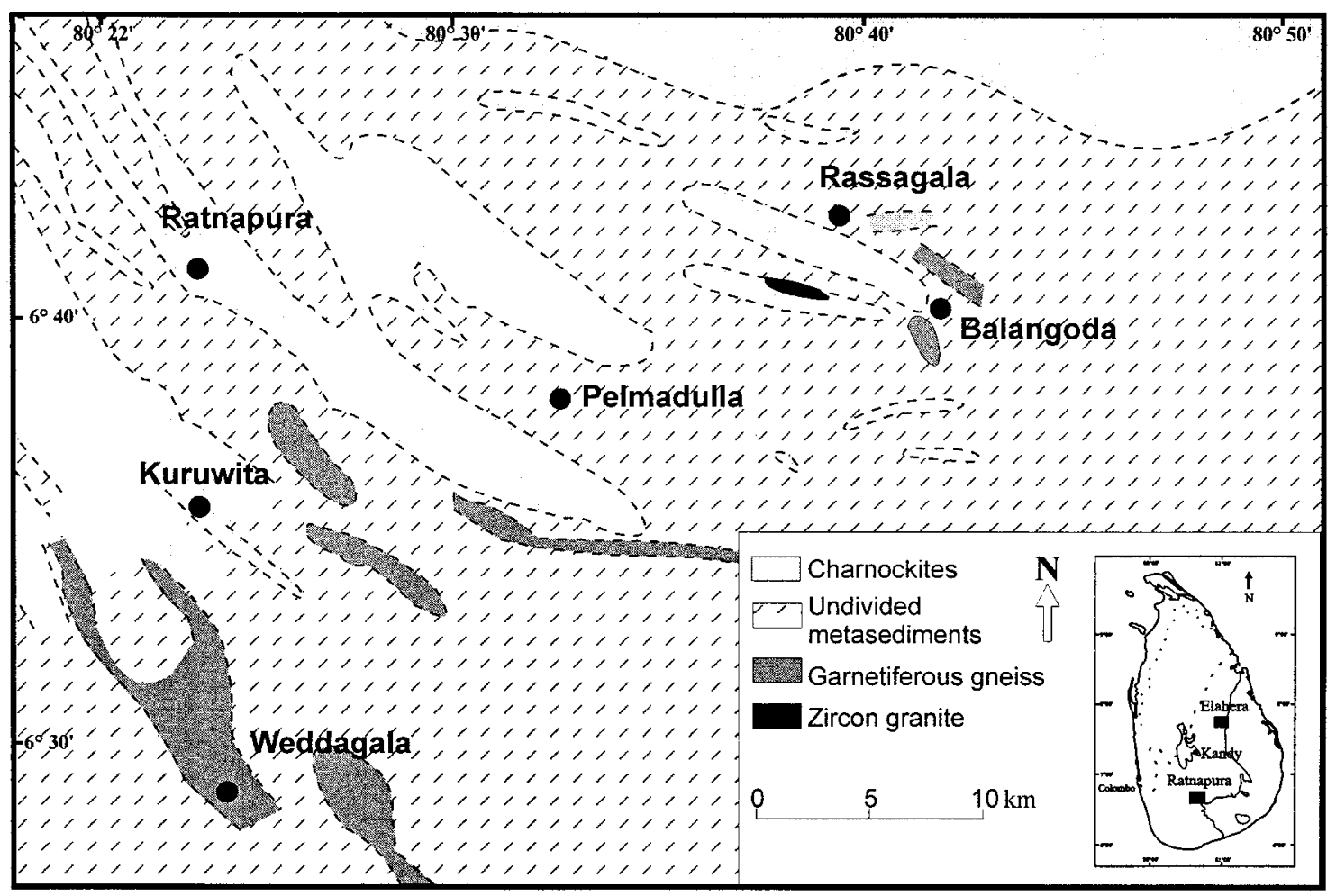

Fig. 3. Geological map of the main Ratnapura gem field. Inset shows the location of the Ratnapura and Elahera gem fields in relation to the main lithotectonic units of Sri Lanka (modified after Rupasinghe \& Dissanayake 1985). 


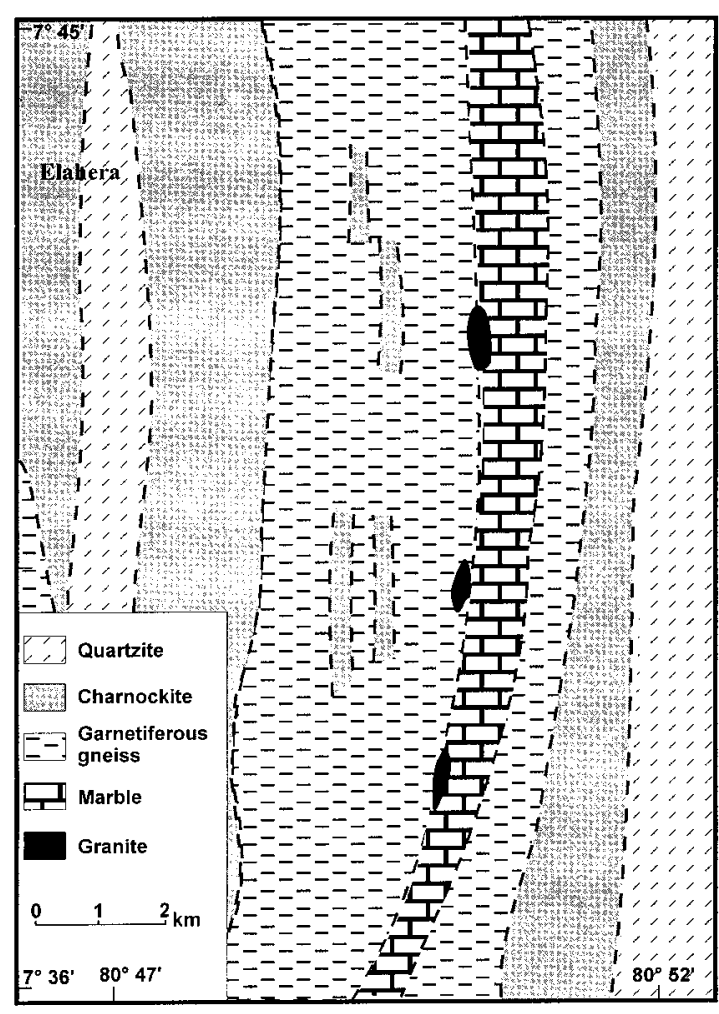

Fig. 4. Geological map of the Elahera gem field (modified after Rupasinghe \& Dissanayake 1985).

amount of gemstones and the deposit is mostly of the residual type, although alluvial deposits are not uncommon. The Elahera gem deposits also lie within the Highland Complex and consist mainly of quartzites, marbles and garnet-sillimanitebiotite gneisses. Silva (1976) reported the occurrence of granites and pegmatites in the Highland Complex and these have a special significance because they are considered source materials for the gemstones.

Silva and Siriwardena (1988) described a corundum-bearing deposit at Bakamuna in the Elahera gem field (Fig. 5). According to these authors, the skarn body was formed by the reaction of pegmatitic fluids with marble. Hydraulic fractures in the rock, an increase in $\mathrm{CO}_{2}$ pressure and dedolomitization had made the rock permeable to fluids. The marble reacted with these fluids to form the corundum.

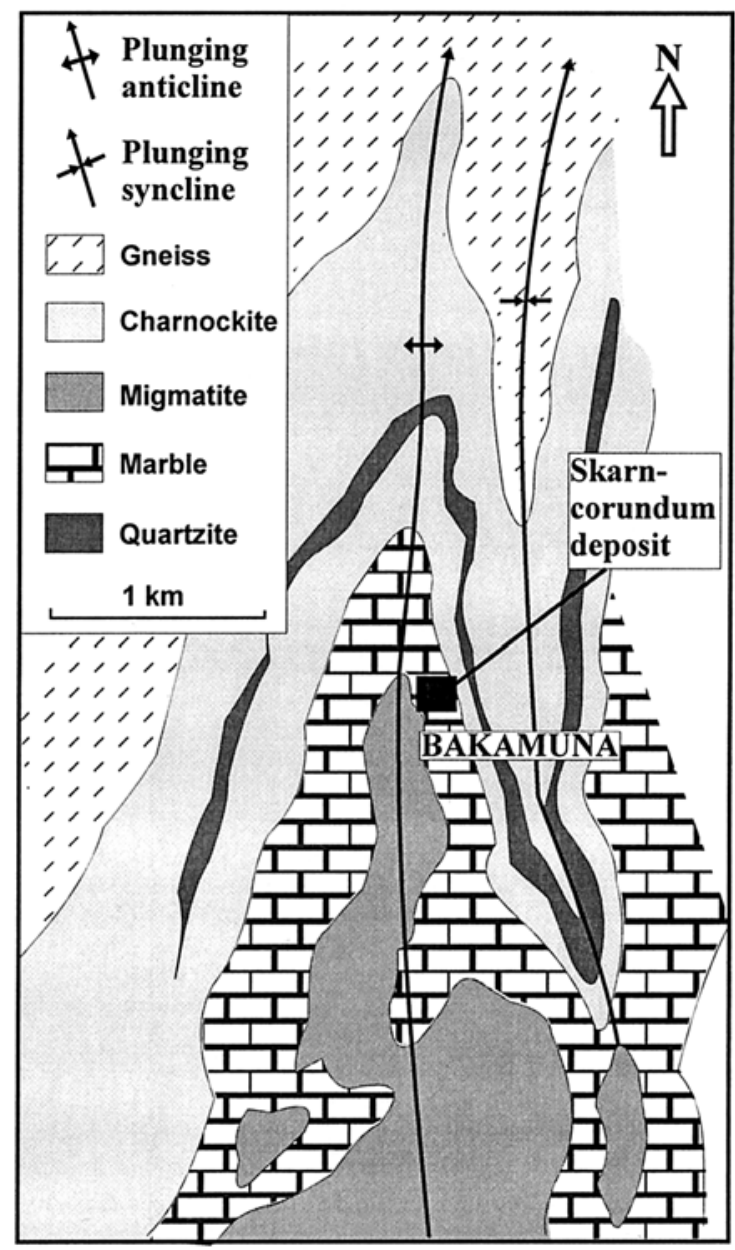

Fig. 5. Geology of the Bakamuna area and the detailed geology of the skarn deposit (after Silva \& Siriwardena 1988).

\section{Corundum-bearing gem pockets of pegmatitic origin}

An interesting occurrence of corundum-bearing gem pockets of pegmatitic origin was described by Kumaratilake and Ranasinghe (1992) from Avissawella and Getahetta, northwest of the main Ratnapura gem field. There are two types of gem pockets: corundum-bearing pockets and hollowtype. The former contains treatable corundum and lesser quantities of yellow and blue corundum while the latter type only contains pyrite. These gem pockets are of pegmatitic origin. 
The moonstone deposit at Meetiyagoda is one of the best examples in Sri Lanka of a pegmatitic type of gem formation and is associated with a large pegmatite vein that crosscuts metamorphic rocks. Malley (1989) has shown that the mineral composition of the deposit is approximately $50 \%$ clay, $40 \%$ feldspar, and 5\% quartz, smoky quartz and opaline silica with traces of sulphides (mostly marcasite) and tourmaline.

\section{MINERALOGY AND GEOCHEMISTRY OF THE GEM DEPOSITS}

Sri Lanka has a wide variety of gem minerals including, among others, corundum, chrysoberyl, zircon, tourmaline, kornerupine, garnets, topaz, spinel and taaffeite. Table 1 gives the key gem minerals of Sri Lanka listed by locality. Fig. 6 gives a general classification of the minerals found in the washed gem gravels of Sri Lanka. Among the heavy minerals found in gem-bearing stream sediments are zircon, garnet, monazite, ilmenite, magnetite and rutile. Recent studies in the Walawe Ganga Basin in southwestern Sri Lanka (Chandrajith 1999) show that some stream sediments contain as much as $50 \mathrm{wt} \%$ of these heavy minerals. Studies by Rupasinghe et al. (1994) indicate that some minerals in the stream sediments are potential indicator minerals for gems: notably $\mathrm{Mg}$-rich ilmenite, geikielite, $\mathrm{Mg}$-rich spinel, Ca-rich scapolite, $\mathrm{Ca}-\mathrm{Mg}$ pyroxene (salite), Ca-rich garnet (grossular) and minerals containing REE such as sphene, davidite and monazite. These appear to be closely associated with the gems themselves and are common in the stream sediments.

The gem-bearing sediments of Sri Lanka are also rich in certain rare minerals as shown in Table 2. These minerals have a unique geochemical signature and are rich in REE, Ta, $\mathrm{Nb}, \mathrm{Zr}, \mathrm{Th}, \mathrm{U}$, Ti, Be and F (Dissanayake \& Rupasinghe 1992). The occurrence in sediments of anomalous concentrations of such elements leads to the discovery of rare minerals such as zirkelite, niobian rutile, gadolinite, chevkinite, samarskite, aeschynite, anatase and fergusonite. Some of the gem minerals, namely serendibite $\mathrm{Ca}_{2}(\mathrm{MgAl})_{6}(\mathrm{Si}, \mathrm{Al}, \mathrm{B})_{6} \mathrm{O}_{22}$, sinhalite $\mathrm{MgAlBO}_{4}$, ceylonite $\mathrm{MgAl}_{2} \mathrm{O}_{4}$, taprobanite $\mathrm{Mg}_{3} \mathrm{Al}_{8} \mathrm{BeO}_{16}$, ekanite $\mathrm{ThCa}_{2} \mathrm{Si}_{8} \mathrm{O}_{22}$ and uvite $\mathrm{WX}_{3} \mathrm{Y}_{6}\left(\mathrm{BO}_{3}\right)_{3} \mathrm{Si}_{6} \mathrm{O}_{18}$ were discovered in Sri Lan$\mathrm{ka}$. These are special varieties of larger families of gem minerals and have unique properties. Within the heavy mineral fractions of the stream sediments, some radioactive minerals such as monazite, zircon, thorianite, thorite and allanite are also abundant. They contain significant concentrations of U, Th, REE and some other trace elements.

\section{Trace elements in the sediments}

Rupasinghe and Dissanayake (1985) studied the geochemistry of the stream sediments that form the Ratnapura and Elahera gem fields and Chandrajith (1999) investigated the geochemistry of those of the Walawe Ganga Basin. The trends in element enrichment in the Ratnapura, Elahera and Walawe Ganga gem fields are put in perspective in Fig. 7, which shows the enrichment factors of elements of the sediments against their average crustal abundances.

In the stream sediments from the three gem fields, most alkali, alkaline earth and transition elements show closely similar enrichment factors. However, in stream sediments from the Elahera gem field, the enrichment factors for most transition elements, $\mathrm{Sr}$ and $\mathrm{Ba}$ are lower than those for stream sediments from the Ratnapura gem field and the Walawe Ganga Basin. Samples from the latter, which is situated southeast of the main Ratnapura gem field (Fig. 1), are particularly enriched in Ti, Zr, U, Th, W, La, Ce, Hf and Ta.

The enrichment or depletion of the elements in the various gem fields reflects the geology, geochemistry and mineralogy of the source regions. In the Ratnapura and Walawe Ganga gem fields, the mineralogy of the sediments, particularly the abundance of minerals such as zircon, monazite, rutile and spinel, mainly controls the geochemistry of the elements. Because of this, those sediment fractions coarser than $63 \mu \mathrm{m}$ are particularly enriched in trace elements, notably REE, Zr, Mo, U, Th and Ta (Chandrajith 1999). It is apparent that the high abundance of zircons in the Walawe Ganga gem field has a marked influence 
Table 1. Key gem minerals of Sri Lanka listed by locality. Topographic sheet numbers are those shown in Fig. 1 (after Dissanayake \& Rupasinghe 1993).

\begin{tabular}{|c|c|c|}
\hline $\begin{array}{l}\text { Topo } \\
\text { No. }\end{array}$ & $\begin{array}{l}\text { graphic Sheet } \\
\text { Name }\end{array}$ & Gem minerals \\
\hline 1 & Polonnaruwa & corundum, garnet \\
\hline 2 & Nalanda & apatite \\
\hline 3 & Elahera & $\begin{array}{l}\text { chrysoberyl, corundum, garnet, iolite (cordierite), kornerupine, } \\
\text { sinhalite, sphene, spinel, zircon }\end{array}$ \\
\hline 4 & Kurunegala & amethyst, apatite, citrine, fluorite, iolite (cordierite), topaz, tourmaline \\
\hline 5 & Rangala & no known deposits \\
\hline 6 & Kandy & amethyst, aquamarine \\
\hline 7 & Hanguranketa & corundum \\
\hline 8 & Nilgala & corundum, garnet, spinel, tourmaline, zircon \\
\hline 9 & Avissawella & $\begin{array}{l}\text { amethyst, andalusite, beryl, chrysoberyl, corundum, diopside, epidote, iolite (cordierite), } \\
\text { kornerupine, garnet, sinhalite, spinel, tourmaline, zircon }\end{array}$ \\
\hline 10 & Hatton & andalusite, corundum, garnet, iolite (cordierite), spinel, topaz \\
\hline 11 & Nuwara Eliya & amethyst, corundum, spinel, zircon \\
\hline 12 & Passara & corundum, ekanite, garnet, kornerupine, spinel, taaffeite, topaz, tourmaline, zircon \\
\hline 13 & Panadura-Horana & $\begin{array}{l}\text { aquamarine, axinite, beryl, chrysoberyl, corundum, garnet, vesuvianite, phenakite, } \\
\text { scapolite, sillimanite, spinel, taaffeite, topaz, tourmaline, zircon }\end{array}$ \\
\hline 14 & Ratnapura & $\begin{array}{l}\text { amethyst, andalusite, apatite, beryl, chrysoberyl, citrine, corundum, diamond, danburite, } \\
\text { diopside, ekanite, garnet, iolite (cordierite), kornerupine, scapolite, sillimanite, sinhalite, } \\
\text { spinel, taaffeite, topaz, tourmaline, zircon }\end{array}$ \\
\hline 15 & Haputale & $\begin{array}{l}\text { andalusite, axinite, beryl, chrysoberyl, corundum, diopside, garnet, vesuvianite, spinel, } \\
\text { topaz, tourmaline, zircon }\end{array}$ \\
\hline 16 & Buttala & corundum, ekanite, garnet, spinel, tourmaline \\
\hline 17 & Alutgama & chrysoberyl, corundum, spinel, zircon \\
\hline 18 & Rakwana & $\begin{array}{l}\text { apatite, aquamarine, axinite, beryl, chrysoberyl, corundum, danburite, diopside, ekanite, } \\
\text { enstatite, fluorite, garnet, kornerupine, spinel, tourmaline, zircon }\end{array}$ \\
\hline 19 & Timbolketiya & garnet \\
\hline 20 & Kataragama & corundum, hiddenite (spodumene), sphene, spinel \\
\hline 21 & Ambalangoda & moonstone (feldspar) \\
\hline 22 & Morawaka & $\begin{array}{l}\text { aquamarine, beryl, chrysoberyl, corundum, danburite, diopside, garnet, sillimanite, } \\
\text { sphene, spinel, tourmaline, zircon }\end{array}$ \\
\hline 23 & Ambalantota & $\begin{array}{l}\text { beryl, chrysoberyl, corundum, garnet, vesuvianite, iolite (cordierite), scapolite, } \\
\text { sillimanite, sinhalite, spinel, tourmaline, zircon }\end{array}$ \\
\hline 24 & Galle & beryl, chrysoberyl, corundum, sphene \\
\hline 25 & Matara & aquamarine, chrysoberyl, corundum, garnet, zircon \\
\hline
\end{tabular}

on the concentration of some of these elements. It has been reported that zircon is a sink for more than 50 elements (Speer 1982). Chandrajith (1999) reported nearly identical average $\mathrm{Zr} / \mathrm{Hf}$ ratios of $73,75,75$ and 71 in four stream sediment size fractions from the Walawe Ganga gem-bearing area. Because of their similar ionic radii, coordination numbers and ionic charges, $\mathrm{Hf}^{4+}(\mathrm{r}=83 \mathrm{pm})$ readily substitutes for $\mathrm{Zr}^{4+}(\mathrm{r}=84 \mathrm{pm})$ in zircon, which occurs as a solid solution series with the 


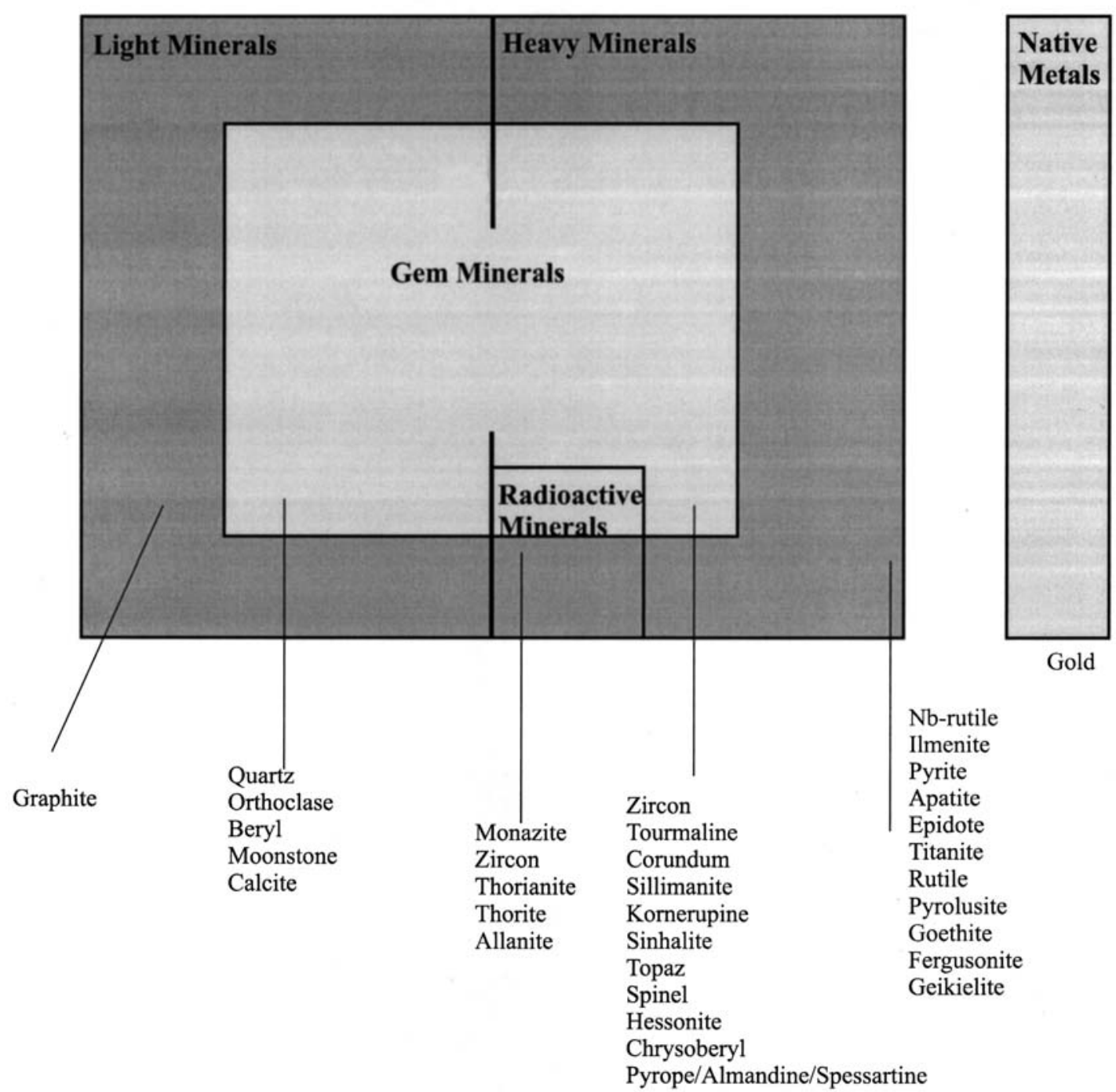

Fig. 6. A general classification of the minerals found in washed gem sediments (after Rupasinghe et al. 1986).

end-members zircon $\left(\mathrm{ZrSiO}_{4}\right)$ and hafnon (Hf$\mathrm{SiO}_{4}$ ). Medenbach (1976) reported that the sum of the concentrations of REE and Y in zircon can be as high as $25 \mathrm{wt} \%$. The enriched concentrations of REE in the Walawe Ganga sediments are due not only to the presence of zircon, but also due to the presence of other minerals such as monazite. The enrichments of $\mathrm{Nb}$, Th and $\mathrm{U}$ are attributed to the occurrence of minerals such as niobian rutile, which acts as a sink for $\mathrm{Nb}, \mathrm{Ta}, \mathrm{Ce}$ and $\mathrm{La}$, and fergusonite, which is a sink for $\mathrm{Y}, \mathrm{Nb}, \mathrm{Ta}$, Th and U. The presence of minerals such as thor- ite and thorianite accounts for the enrichments of $\mathrm{Th}$ and $\mathrm{U}$ in the sediments. The enrichments of base metals $(\mathrm{Co}, \mathrm{Ni}, \mathrm{Cu})$ in the Ratnapura gem sediments, though of minor significance, are presumably due to the basic rocks in the terrain, which are hosts for these metals.

\section{Origin of rare metal enrichments in the sediments}

The above discussion has shown that the stream sediments, particularly those in southwestern and 
Table 2. Rare minerals found in the gem sediments of Sri Lanka (after Dissanayake \& Rupasinghe 1992).

\begin{tabular}{|c|c|c|c|}
\hline Mineral & SG & Chemical formula & Other elements found \\
\hline Ekanite & 3.28 & $\mathrm{~K}(\mathrm{Ca}, \mathrm{Na})_{2} \mathrm{Th}\left(\mathrm{Si}_{8} \mathrm{O}_{20}\right) \mathrm{CaTi}\left(\mathrm{O} / \mathrm{SiO}_{4}\right)$ & \\
\hline Serendibite & 3.4 & $(\mathrm{Ca}, \mathrm{Mg})_{5}(\mathrm{AlO})_{5}\left(\mathrm{BO}_{3} /\left(\mathrm{SiO}_{4}\right)_{3}\right)$ & \\
\hline Anatase & 3.9 & $\mathrm{TiO}_{2}$ & $\mathrm{Nb}, \mathrm{Ta}, \mathrm{REE}$ \\
\hline Allanite & 4 & $(\mathrm{Ca}, \mathrm{Ce})\left(\mathrm{Fe}^{3+}, \mathrm{Fe}^{2+}\right) \mathrm{Al}_{2} \mathrm{O}\left(\mathrm{SiO}_{4}\right)\left(\mathrm{Si}_{2} \mathrm{O}_{7}\right)(\mathrm{OH})$ & \\
\hline Perovskite & 4 & $\mathrm{CaTiO}_{3}$ & $\mathrm{Nb}, \mathrm{Ta}, \mathrm{REE}$ \\
\hline Zirkelite & 4 & $(\mathrm{Ca}, \mathrm{Ce}, \mathrm{Y}, \mathrm{Fe})(\mathrm{Ti}, \mathrm{Zr}, \mathrm{Th})_{3} \mathrm{O}_{7}$ & $1-14 \% \mathrm{U}_{2} \mathrm{O}_{8}, \mathrm{REE}$ \\
\hline Rutile & 4 & $\mathrm{TiO}_{2}$ & $\mathrm{Nb}, \mathrm{Ta}, \mathrm{Fe}$ \\
\hline Gadolinite & $4-4.7$ & $\mathrm{Y}_{2} \mathrm{Fe}^{2+} \mathrm{Be}_{2}\left(\mathrm{O} / \mathrm{SiO}_{4}\right)_{2}$ & \\
\hline Geikielite & 4.05 & $\mathrm{MgTiO}_{3}$ & \\
\hline Microlite & 4.2 & $(\mathrm{Ca}, \mathrm{Na})_{2}(\mathrm{Ta}, \mathrm{Nb}, \mathrm{Ti})_{2} \mathrm{O}_{6}(\mathrm{OH}, \mathrm{O}, \mathrm{F})$ & \\
\hline Zircon & $4.3-4.5$ & $\mathrm{ZrSiO}_{4}$ & U, Th, Hf, REE \\
\hline Chromite & $4.5-4.8$ & $(\mathrm{Fe}, \mathrm{Mg}) \mathrm{Cr}_{2} \mathrm{O}_{4}$ & \\
\hline Ce-Monazite & $4.8-5$ & $\mathrm{CePO}_{4}$ & U, Th, REE \\
\hline Columbite & 5 & $(\mathrm{Fe}, \mathrm{Mn})(\mathrm{Ta}, \mathrm{Nb})_{2} \mathrm{O}_{6}$ & \\
\hline Baddeleyite & 5 & $\mathrm{ZrO}_{2}$ & \\
\hline Tantalite & $5-8$ & $(\mathrm{Fe}, \mathrm{Mn})(\mathrm{Nb}, \mathrm{Ta})_{2} \mathrm{O}_{6}$ & \\
\hline Samarskite & 5.24 & $(\mathrm{Y}, \mathrm{U}, \mathrm{Ca})_{2}\left(\mathrm{Nb}, \mathrm{Fe}^{2+}\right)_{2}(\mathrm{O}, \mathrm{OH})_{6}$ & Ta, REE \\
\hline Thorite & 5.3 & $\mathrm{ThSiO}_{4}$ & $\mathrm{U}$ \\
\hline Fergusonite & $5.6-5.8$ & $\mathrm{Y}(\mathrm{Nb}, \mathrm{Ta}) \mathrm{O}_{4}$ & $4 \% \mathrm{U}_{3} \mathrm{O}_{8}, \mathrm{REE}$ \\
\hline Scheelite & $5.9-6.1$ & $\mathrm{CaWO}_{4}$ & \\
\hline Cassiterite & $6.8-7.1$ & $\mathrm{SnO}_{2}$ & $\mathrm{Nb}, \mathrm{Ta}, \mathrm{Ti}, \mathrm{Mn}, \mathrm{Zr}, \mathrm{W}, \mathrm{Fe}$ \\
\hline Thorianite & 9.7 & $(\mathrm{Th}, \mathrm{U}) \mathrm{O}_{2}$ & \\
\hline
\end{tabular}

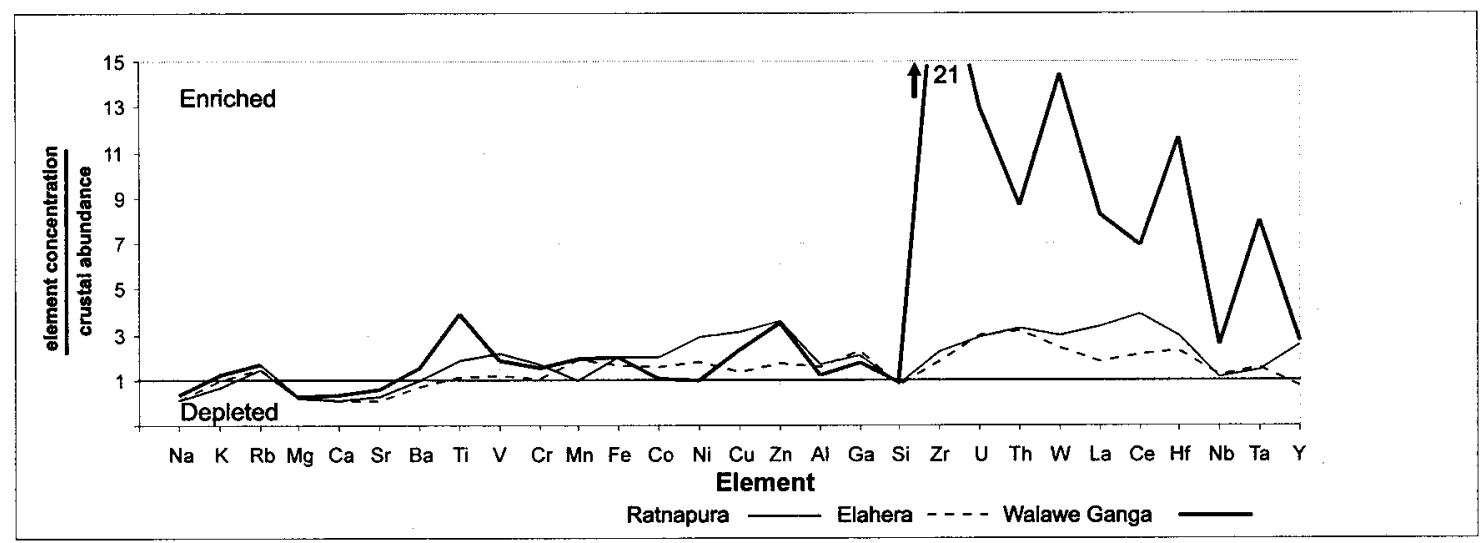

Fig. 7. Comparison of the enrichment factors of the elements in the $-63 \mu \mathrm{m}$ sediment fractions with their average crustal abundances of Wedepohl (1995) for Ratnapura, Elahera and Walawe gem fields (after Rupasinghe \& Dissanayake 1985, Chandrajith 1999)

southeastern Sri Lanka, are rich not only in gem minerals but in trace elements as well. The mineral sources, particularly those rich in trace elements such as $\mathrm{Zr}$, Hf, REE, Ta, Nb, U and Th, are associated with late stage magmatic events that brought about metal-rich solutions through igneous activity that included pegmatite emplace- ment. The origin of the sources is closely related to the geologic and tectonic history of the Highland Complex. The restriction of both the gem mineralization and the metal enrichments mostly to this area indicates late magmatic activity, which possibly post-dated the main granulite facies metamorphism. Structural and geo- 


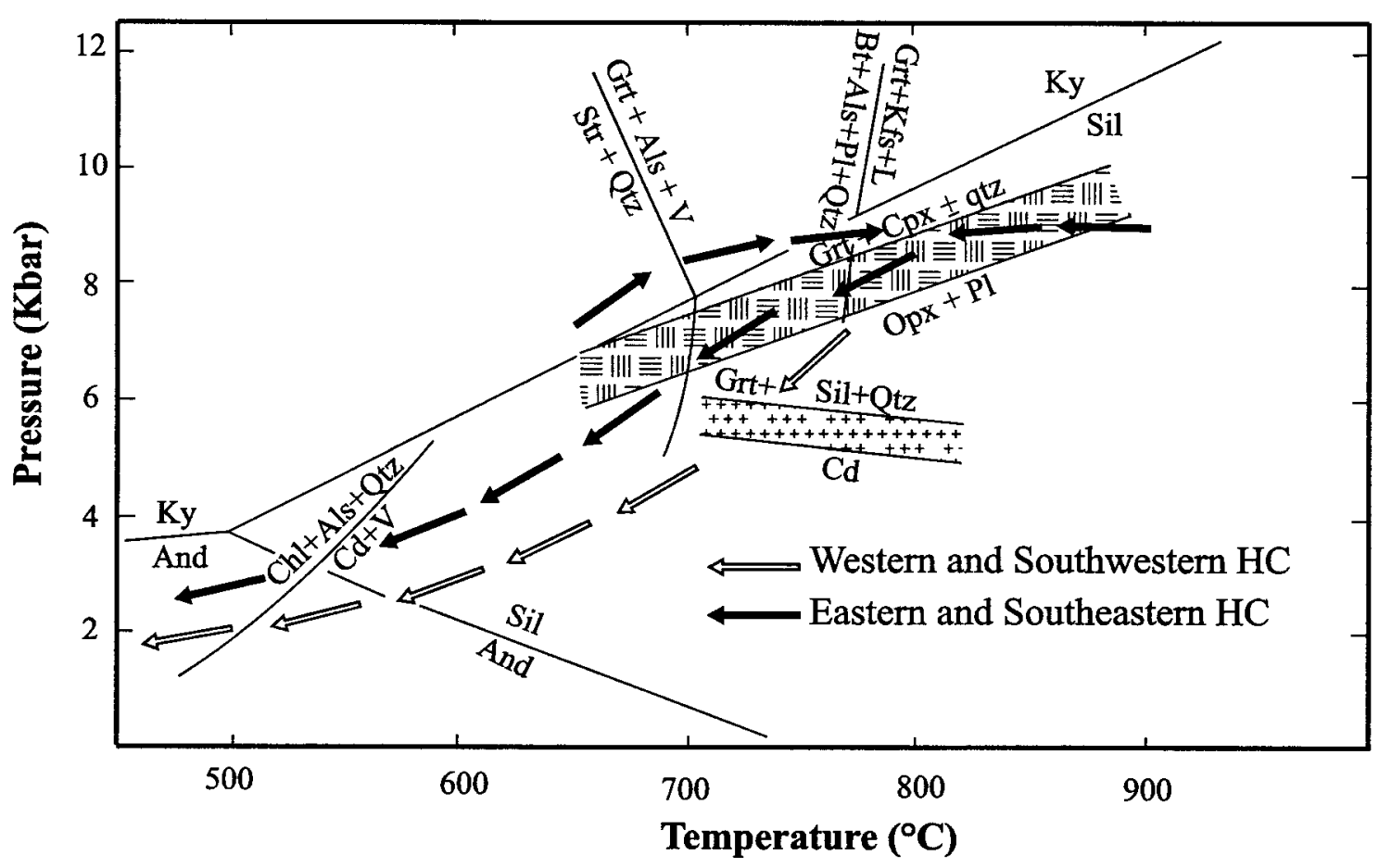

Fig. 8. P-T-t paths for the Highland Complex (modified after Prame 1995).

logical investigations support this view (Voll \& Kleinschrodt 1991).

The granulite terrain of Sri Lanka is considered to be a continuous crustal block representing the middle to lower crust (Prame 1991). Mineral parageneses indicative of various P-T conditions were formed either as a result of the regional variation in metamorphic pressures, or at different stages of the retrograde P-T path (Fig. 8).

Both thermobarometric studies and detailed geological and petrological studies have revealed that southeastern Sri Lanka, particularly near the Highland Complex-Vijayan Complex boundary, has undergone maximum deformation and compression, which resulted in intense thrusting (Kröner et al. 1991). The significant mineralizations occur in these areas. The late stage magmatic activity, particularly granite and pegmatite formation, presumably took place during the Pan-African geological events around $550 \mathrm{Ma}$. Such metallogenic activity was common during the PanAfrican period in the Gondwana terrains of India,
Sri Lanka, Madagascar, Eastern Africa and Antarctica (Santosh \& Drury 1988, Yoshida et al. 1990). Pegmatites are widely distributed in Sri Lanka and are interspersed with granitic intrusions and other bodies of magmatic origin. The markedly high $\mathrm{Zr}$, Hf, REE and Ta enrichments are interpreted to be due major fractionation of the source granitic melts.

Voll and Kleinschrodt (1991) considered that the late and ubiquitous occurrence of pegmatites is indicative of the presence of granitic bodies below the present surface level, and that such granites could have formed at even deeper levels. The southeastern part of Sri Lanka, i.e. the area represented by the Walawe Ganga Basin, is particularly rich in pegmatitic material containing rare trace elements. The fact that the deepest crustal levels of Sri Lanka are in the southeast and east suggests that this material could have formed at deeper crustal levels.

Anomalously high concentrations of fluorides were noted by Dissanayake and Weerasooriya 
(1986) in a hydrogeochemical survey carried out on the Highland Complex-Vijayan Complex boundary, which is known to be a mineralized belt (Dissanayake 1985). Base metals such as $\mathrm{Cu}, \mathrm{Zn}$, $\mathrm{V}$ and Co also showed relative enrichments in this mineralized belt. Dissanayake and Weerasooriya (1986) attributed the increase in fluorides to granite magmatism concomitant with the enrichment of volatiles and mineralizers. The presence of uraniferous granites, hot springs, serpentinites, massive sulphide deposits with $\mathrm{Cu}, \mathrm{Ag}, \mathrm{B}, \mathrm{Be}, \mathrm{Pb}$, $\mathrm{V}$, Co and $\mathrm{Zn}$ in the mineralized belt, in association with high fluoride concentrations, was taken to be indicative of a deep-seated fracture, in which fluoride might have acted as a mineralizing agent.

Fluoride is especially well known as an indicator of mineralization, particularly for occurrences of hydrothermal origin (Lalonde 1976). Fluorine-rich granitic rocks are known to contain elevated concentrations of high field strength and related elements such as $\mathrm{U}, \mathrm{Th}, \mathrm{Zr}, \mathrm{Hf}, \mathrm{Nb}, \mathrm{Ta}$, Ti, Sn, Mo, W and REE (Pollard et al. 1987, Keppler 1993).

\section{CONCLUSIONS}

The Highland Complex of Sri Lanka, a high-grade metamorphic terrain, is one of the most prominent gem-bearing terrains in the world. The gem deposits are mostly of the sedimentary type, and these are classified as residual, eluvial and alluvial. Mineralogically, there is a wide variety of gemstones with corundum being the characteristic and most important gem mineral. Sri Lanka's gem-bearing sediments, which are most abundant in the granulitic terrains of the southwest and southeast, contain markedly enriched concentrations of high field strength and associated elements such as $\mathrm{Zr}$, Ta, Nb, Hf and REE. Highly differentiated granites and pegmatites contain phases such as zircon, rutile and monazite that acted as sinks for these elements. The high concentrations of mineralizers such as fluoride at the HighlandVijayan boundary close to the metal-enriched regions probably had a marked influence on the enrichment of the elements in these minerals.
ACKNOWLEDGEMENTS. CBD acknowledges with thanks a grant from the Alexander von Humboldt Foundation and RC gratefully acknowledges a grant from the German Academic Exchange Service (DAAD).

\section{REFERENCES}

Chandrajith, R. 1999. Petrological, mineralogical and geochemical studies of the Walawe Ganga Basin, Sri Lanka, with special emphasis on the geochemistry of high field strength elements including rare earth elements. Ph.D. thesis, University of Erlangen-Nürnberg, Germany.

Cooray, P.G. 1962. Charnockites and their associated gneisses in the Precambrian of Ceylon. Quarterly Journal of the Geological Society 118, 239-273.

Cooray, P.G. 1984. Geology, with special reference to the Precambrian. In: Fernando, C.H. (ed.) Ecology and Biogeography in Sri Lanka. Monographia Biologicae 1, 134.

Cooray, P.G. 1994. The Precambrian of Sri Lanka: a historical review. Precambrian Research 66, 3-18.

Cooray, P.G. \& Kumarapeli, P.S. 1960. Corundum in biotite sillimanite gneiss from near Polgahawela, Sri Lanka. Geological Magazine XCVII, 480-487.

Dahanayake, K., Liyanage, A.N. \& Ranasinghe, A.P. 1980. Genesis of sedimentary gem deposits in Sri Lanka. Sedimentary Geology 25, 105-115.

Dissanayake, C.B. 1985. Application of plate tectonics to mineral exploration - discovery of a mineralised belt in Sri Lanka. In: Dissanayake, C.B. \& Cooray, P.G. (eds.) Recent Advances in the Geology of Sri Lanka. CIFEG, Paris, 41-47.

Dissanayake, C.B. 1991. Gem deposits of Sri Lanka - Prospector's guide map. Export Development Board, Sri Lanka.

Dissanayake, C.B. \& Rupasinghe, M.S. 1986. The niobium and yttrium abundances in the sedimentary gem deposits of Sri Lanka. Journal of the National Science Council, Sri Lanka 14, 55-74.

Dissanayake, C.B. \& Rupasinghe, M.S. 1992. Application of geochemistry to exploration for gem deposits, Sri Lanka. Journal of Gemmology 23, 165-175.

Dissanayake, C.B. \& Rupasinghe, M.S. 1993. A prospector's guide map of the gem deposits of Sri Lanka. Gems and Gemmology 29, 173-181.

Dissanayake, C.B. \& Rupasinghe, M.S. 1995. Classification of gem deposits of Sri Lanka. Geologie en Mijnbouw 74, 79-88.

Dissanayake, C.B., Rupasinghe, M.S. \& Mendis, D.P.J. 1994. Geochemical exploration for gem deposits in Sri Lanka - application of discriminant analysis. Chemie der Erde 54, 33-47.

Dissanayake, C.B. \& Weersooriya, S.V.R. 1986. Fluoride as an indicator of mineralization - Hydrogeochemistry of a Precambrian mineralised belt in Sri Lanka. Chem- 
ical Geology 56, 257-270.

Gunaratne, H.S. \& Dissanayake, C.B. 1995. Gems and gem deposits of Sri Lanka. Colombo: National Gems and Jewellery Authority. 203 p.

Hansen, E.C., Janarahan, A.S., Newton, R.C., Prame, W.K.B.N. \& Ravindrakumar, G.R. 1987. Arrested charnockite formation in southern India and Sri Lanka. Contributions to Mineralogy and Petrology 96, 225-244.

Jayawardena, D. de S. \& Carswell, D.A. 1976. The geochemistry of charnockites and their constituent ferromagnesian minerals from the Precambrian of Southeast Sri Lanka (Ceylon). Mineralogical Magazine 40, 541554.

Katz, M.B. 1986. Review of the geology of the gemstones of Sri Lanka. The Australian Gemmologist 20, 52-61.

Keppler, H. 1993. Influence of fluorine on the enrichment of high field strength trace elements in granitic rocks. Contributions to Mineralogy and Petrology 114, 479488.

Kröner, A., Cooray, P.G. \& Vitanage, P.W. 1991. Lithotectonic subdivision of the Precambrian basement in Sri Lanka. In: Kröner, A. (ed.) The Crystalline Crust of Sri Lanka. Part I, Summary of Research of the German Sri Lanka Consortium. Geological Survey Department of Sri Lanka, Professional Paper 5, 5-21.

Kumartilake, W.L.D.R.A. \& Ranasinghe, U.N. 1992. Unusual corundum-bearing pockets at Avissawella and Getahetta, Sri Lanka. Zeitschrift der Deutschen Gemmologischen Gesellschaft 41, 7-16.

Lalonde, J. 1976. Fluorine - an indicator of mineral deposits. Canadian Mineral and Metallurgy Bulletin 69, 110-122.

Maesschalck, A.A.D.E. \& Oen, I.C. 1989. Fluid and mineral inclusions in corundum from gem gravels in Sri Lanka. Mineralogical Magazine 53, 539-545.

Madenbach, O. 1976. Geochemie der Elemente in Zirkon und ihre räumliche Verteilung - Eine Untersuchung mit der Elektronenstrahlmikrosonde. Master's thesis, Ruprecht Karl Universität, Heidelberg.

Malley, J. 1989. Zur Genese von Edelsteinen am Beispiel der Insel Sri Lanka. Ph.D Thesis. University of Mainz, Germany.

Mendis, D.P.J., Rupasinghe, M.S. \& Dissanayake, C.B. 1993. Application of structural geology in the exploration of residual gem deposits of Sri Lanka. Bulletin of the Geological Society of Finland 65, 31-40.

Milisenda, C.C., Pohl, J.R. \& Hofmann, A.W. 1991. Geochemistry of charnockite formation at Kurunegala, Sri Lanka. In: Kröner, A. (ed.) The Crystalline Crust of Sri Lanka. Part I, Summary of Research of the German Sri Lanka Consortium. Geological Survey Department of Sri Lanka, Professional Paper 5, 141-150.

Munasinghe, T. \& Dissanayake, C.B. 1981. The origin of gemstones of Sri Lanka. Economic Geology 76, 12161224.

Pollard, P.J., Pichavant, M. \& Charoy, B. 1987. Contrasting evolution of fluorine- and boron-rich tin systems. Mineralium Deposita 22, 315-321.
Prame, W.K.B.N. 1991. Metamorphism and nature of granulite facies crust in Southwest Sri Lanka - Characterization by pelitic/psammo-pelitic rocks and associated granulites. In: Kröner, A. (ed.) The Crystalline Crust of Sri Lanka. Part I, Summary of Research of the German - Sri Lanka Consortium. Geological Survey Department of Sri Lanka, Professional Paper 5, 188-200.

Prame, W.K.B.N. 1995. Geothermobarometry and P-T history of Sri Lankan granulites. In: Dahanayake, K. (ed.) Handbook on Geology and Mineral Resources of Sri Lanka. Souvenir Publication, $2^{\text {nd }}$ South Asian Geological Congress, Colombo, 53-59.

Rupasinghe, M.S. \& Dissanayake, C.B. 1984. Rare earth element abundance in the sedimentary gem deposits of Sri Lanka. Lithos 17, 329-342.

Rupasinghe, M.S. \& Dissanayake, C.B. 1985. A preliminary geochemical study of sedimentary gem deposits of Sri Lanka. Chemie der Erde 44, 281-298.

Rupasinghe, M.S., Dissanayake, C.B. \& Mendis, D.P.J. 1994. Use of indicator minerals in gem exploration: study of a granulitic terrain in Sri Lanka. Journal of the Southeast Asian Earth Sciences 9, 249-254.

Rupasinghe, M.S., Senaratne, A. \& Dissanayake, C.B. 1986. Light, heavy and rare minerals in washed gem gravels of Sri Lanka. Journal of Gemmology 20, 177184.

Santosh, M. \& Drury, S.A. 1988. Alkali granites with PanAfrican affinities from Kerala, South India. Journal of Geology 96, 616-626.

Schenk, V., Raase, P. \& Schumacher, R. 1991. Metamorphic zonation and P-T history of the Highland complex in Sri Lanka. In: Kröner, A. (ed.) The Crystalline Crust of Sri Lanka. Part I, Summary of Research of the German - Sri Lanka Consortium. Geological Survey Department of Sri Lanka, Professional Paper 5, 150-164.

Silva, K.K.M.W. 1976. Some geological aspects of the Elahera gem fields, Sri Lanka. Association for the Advancement of Sciences 32 (abstract).

Silva, K.K.M.W. \& Siriwardena, C.H.E.R. 1988. Geology and the origin of the corundum-bearing skarn at Bakamuna, Sri Lanka. Mineralium Deposita 23, 816-190.

Speer, J.A. 1982. Zircon. In: Ribbe, P.H. (ed.) Orthosilicates. Reviews in Mineralogy, Vol. 5. Mineralogical Society of America, 67-112.

Spencer, E. 1930. A contribution to the study of moonstone from Ceylon and other areas and of the stability relations of the alkali feldpars. Mineralogical Magazine 23, 186-190.

Vitanage, P.W. 1985. The geology, structure and tectonics of Sri Lanka and South India. In: Dissanayake, C.B. \& Cooray, P.G. (eds.) Recent Advances in the Geology of Sri Lanka, CIFEG, Paris, 5-15.

Voll, G. \& Kleinschrodt, R. 1991. Sri Lanka structural, magmatic and metamorphic development of Gondwana fragment. In: Kröner, A. (ed.) The Crystalline Crust of Sri Lanka. Part I, Summary of Research of the German - Sri Lanka Consortium. Geological Survey Department of Sri Lanka, Professional Paper 5, 150-164. 
Wadia, D.N. \& Fernando, L.J.D. 1945. Gems and semi-precious stones of Ceylon. Ceylon Department of Mineralogy, Professional Paper 2, 13-44.

Wedepohl, K.H. 1995. The composition of the continental crust. Geochimica et Cosmochimica Acta 59, 12171232.
Yoshida, M., Funaki, M. \& Vitanage, P.W. 1990. Juxtaposition of India - Sri Lanka - Antarctica in Proterozoic to Mesozoic Gondwanaland. In: Hiroi, Y. \& Motoyoshi, Y. (eds.) Study of geologic correlation between Sri Lanka and Antarctica (1988-1989). Chiba University, Japan, 118-131. 